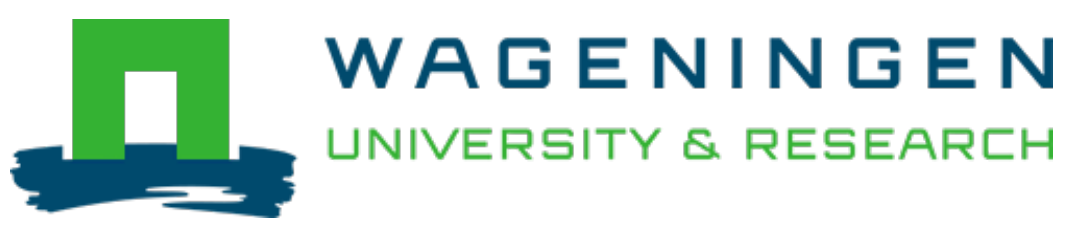

\title{
Through the dam into troubled waters : Combined effects of stream fragmentation, habitat deterioration, and poor water quality on lowland stream fish distribution
}

\author{
River Research and Applications \\ Puijenbroek, Peter J.T.M.; Buijse, Anthonie D.; Kraak, Michiel H.S.; Verdonschot, Piet F.M. \\ https://doi.org/10.1002/rra.3829
}

This publication is made publicly available in the institutional repository of Wageningen University and Research, under the terms of article $25 \mathrm{fa}$ of the Dutch Copyright Act, also known as the Amendment Taverne. This has been done with explicit consent by the author.

Article 25 fa states that the author of a short scientific work funded either wholly or partially by Dutch public funds is entitled to make that work publicly available for no consideration following a reasonable period of time after the work was first published, provided that clear reference is made to the source of the first publication of the work.

This publication is distributed under The Association of Universities in the Netherlands (VSNU) 'Article $25 \mathrm{fa}$ implementation' project. In this project research outputs of researchers employed by Dutch Universities that comply with the legal requirements of Article $25 \mathrm{fa}$ of the Dutch Copyright Act are distributed online and free of cost or other barriers in institutional repositories. Research outputs are distributed six months after their first online publication in the original published version and with proper attribution to the source of the original publication.

You are permitted to download and use the publication for personal purposes. All rights remain with the author(s) and / or copyright owner(s) of this work. Any use of the publication or parts of it other than authorised under article $25 \mathrm{fa}$ of the Dutch Copyright act is prohibited. Wageningen University \& Research and the author(s) of this publication shall not be held responsible or liable for any damages resulting from your (re)use of this publication.

For questions regarding the public availability of this publication please contact openscience.library@wur.nl 


\title{
Through the dam into troubled waters: Combined effects of stream fragmentation, habitat deterioration, and poor water quality on lowland stream fish distribution
}

\author{
Peter J.T.M. van Puijenbroek ${ }^{1} \odot$ | Anthonie D. Buijse ${ }^{2}$ | Michiel H.S. Kraak $^{3}$ | \\ Piet F.M. Verdonschot ${ }^{3,4}$
}

${ }^{1} \mathrm{PBL}$ Netherlands Environmental Assessment Agency, The Hague, The Netherlands

${ }^{2}$ Department of Freshwater Ecology \& Water Quality, Deltares, Utrecht, The Netherlands

${ }^{3}$ University of Amsterdam, IBED, Amsterdam, The Netherlands

${ }^{4}$ Wageningen Environmental Research, WUR, Wageningen, The Netherlands

\section{Correspondence}

Peter J.T.M. van Puijenbroek, PBL Netherlands Environmental Assessment Agency, Bezuidenhoutseweg 30, 2594 AV Den Haag, The Netherlands.

Email: peter.vanpuijenbroek@pbl.nl

\begin{abstract}
This study aimed to distinguish the contribution of stream fragmentation and poor habitat and water quality to the decline in riverine fish species. The species presence was related to the number of barriers between a specific lowland stream section and the main river and to the length of the stream section remaining between two barriers. To investigate the relationship between the absence of fish species and poor ecological water quality, the EQR and stream velocity indices were compared between accessible sites where the fish was either present or absent. $79 \%$ of the $1039 \mathrm{~km}$ lowland stream length was disconnected from the river Meuse by one or more barriers and $34 \%$ by more than 5 barriers, while $28 \%$ of all stream sections were shorter than $2.5 \mathrm{~km}$. Only $2 \%$ of sites scored a very good water quality, while all study sites were characterized by (very) slow flowing waters $(<0.15 \mathrm{~m} / \mathrm{s}$ ). As many fish passages are built to improve connectivity, fish passages do not improve habitat quality. Gudgeon and stone loach were hardly affected by stream fragmentation, and only slightly by too short stream sections. Ide was moderately affected, while the migratory species chub and dace were severely affected by stream fragmentation. Chub and dace were also sensitive to poor habitat and water quality. Distinguishing the effects of stream fragmentation, habitat deterioration, and poor water quality on lowland stream fish distribution increased the understanding of the reasons for the presence and absence of species and may aid effective management and restoration efforts.
\end{abstract}

KEYWORDS

barriers, connectivity., fish distribution, habitat deterioration, lowland streams, stream fragmentation, stream velocity, water quality

\section{1 | INTRODUCTION}

Fragmentation of streams and rivers by dams and weirs is one of the major threats to riverine ecosystems worldwide (Dudgeon et al., 2006; Nilsson, Reidy, Dynesius, \& Revenga, 2005; WWF, 2016). Many lowland streams in the NW-European plain are also affected by fragmentation (Birnie-Gauvin, Aarestrup, Riis, Jepsen, \& Koed, 2017;
Blanchet, Rey, Etienne, Lek, \& Loot, 2010; Brevé, Buijse, Kroes, Wanningen, \& Vriese, 2014). In Europe, there are at least 1.2 million barriers streams (Belletti et al., 2020), and for example in Great Britain, only $3.3 \%$ of the total river network of Great Britain is fully connected and that only $1 \%$ of the rivers are free of artificial barriers (Jones et al., 2019). Fragmentation of streams and rivers includes reduced connectivity (Aarts, van den Brink, \& Nienhuis, 2004; Cote, Kehler, 
Bourne, \& Wier, 2008) and the reduced size of the stream sections remaining between two barriers (Fahrig, 2003; Fuller, Doyle, \& Strayer, 2015).

Stream fragmentation affects the upstream migration of riverine species (de Leeuw \& Winter, 2008; Fuller et al., 2015; Fullerton et al., 2010; Radinger et al., 2017), which often results in a decline in numbers of migratory fish (Aarts et al., 2004; Brown et al., 2013; Guo et al., 2018; Harris, Kingsford, Peirson, \& Baumgartner, 2017; Noble, Cowx, Goffaux, \& Kestemont, 2007). On a European scale, van Puijenbroek et al. (2018) demonstrated a dramatic decline in the number of species that migrate from the sea to the rivers to spawn, with many rivers being devoid of any migratory fish species. In addition, other riverine fish species may be affected by fragmentation when migrating between different habitats up- and downstream during different seasons and life-stages (de Leeuw \& Winter, 2008; Lothian et al., 2019; Lucas \& Baras, 2001; Pollux, Korosi, Verberk, Pollux, \& van der Velde, 2006). Where upstream migration can be mitigated with fish passages, facilitating safe downstream migration, which is affected by hydropower turbines and other types of barriers, has been less studied (Calles, Rivinoja, \& Greenberg, 2013). Disrupted migration is, therefore, a major reason for the decline of riverine fish species (Brevé et al., 2014; Brown et al., 2013; Guo et al., 2018; Harris et al., 2017; Noble et al., 2007).

Fragmentation of rivers and streams may also affect the physical parameters and the habitat quality of the remaining stream sections both upstream and downstream and results in a discontinuity for physical and biological characteristics (Birnie-Gauvin et al., 2017; Mueller, Pander, \& Geist, 2011; Stanford \& Ward, 2001; Ward \& Stanford, 1983). Downstream effects of dams and weirs include changes in flow regime, sediment and nutrient transport, and water temperature (Fuller et al., 2015). The most obvious upstream effects are the loss of flow rate and an increase in depth, which subsequently leads to sedimentation, decreased dissolved oxygen concentrations, and changes in water temperature (Birnie-Gauvin et al., 2017; Petts, 1984; Poff \& Hart, 2002). Moreover, in lowland streams the length of the water body affected by the impoundment tends to be longer, due to the gentle slope (Birnie-Gauvin et al., 2017). On top of the adverse effects of fragmentation and habitat deterioration, freshwater ecosystems in densely populated and heavily exploited lowland areas are also impacted by pollution, resulting in poor water quality (de Baat, Kraak, van der Oost, de Voogt, \& Verdonschot, 2019; de Vries, Kraak, Verdonschot, \& Verdonschot, 2019; dos Reis Oliveira, Kraak, van der Geest, Naranjo, \& Verdonschot, 2018; Paul \& Meyer, 2001; Riis \& Sand-Jensen, 2001).

In multistressed lowland streams, migratory fish species may thus be confronted with four alternative scenarios: (1) The stream is accessible and the habitat and water quality are good; (2) The stream is accessible, but the habitat and water quality are poor; (3) The stream is inaccessible, but the habitat and water quality are good; (4) The stream is inaccessible and the habitat and water quality are poor. To understand the reasons for the presence and absence of species, to aid effective management and to support restoration efforts, it is thus of the utmost importance to distinguish the contribution of stream fragmentation and poor habitat and water quality to the decline in riverine fish species. The aim of this study was, therefore, to unravel the combined effects of stream fragmentation and poor habitat and water quality on lowland stream fish distribution.

To this end, five riverine fish species with different migration characteristics were selected, inhabiting eight multistressed lowland streams, suffering from fragmentation, habitat deterioration, and poor water quality. Monitoring programs of the local water authorities revealed fish declines in $71 \%$ of all stream sections and showed that $40 \%$ of the historical number of species had disappeared. To unravel the contribution of stream fragmentation and poor habitat and water quality to lowland stream fish species distribution, the presence of the species was related to the number of barriers between a specific stream section and the main river and the length of the stream section remaining between two barriers. To evaluate if the absence of fish species could be related to poor habitat and water quality, the ecological quality ratio (EQR), and stream velocity indices were compared between sites where the fish was present whether the section was accessible or not and sites where the fish was absent, although the section was accessible.

\section{2 | MATERIALS AND METHODS}

\subsection{Selected fish species}

Five more common and well monitored riverine fish species with different migration capacities were selected: chub (Leuciscus cephalus Linnaeus, 1758), dace (Leuciscus leuciscus Linnaeus, 1758), ide (Leuciscus idus Linnaeus, 1758), stone loach (Barbatula barbatula Linnaeus, 1758), and gudgeon (Gobio gobio Linnaeus, 1758). The selected species all prefer clear, oxygen rich flowing streams (Brevé et al., 2014). Chub and dace migrate upstream to spawn and between different habitats upand downstream during different seasons and life-stages (Brevé et al., 2014; de Leeuw \& Winter, 2008; Lothian et al., 2019; Lucas \& Baras, 2001; Pollux et al., 2006), although they can also have nonmigratory populations (Blanchet et al., 2010). Migration of ide may vary substantially between individuals within a single population, ranging from only a few km to up to 100 km (Brevé et al., 2014; de Leeuw \& Winter, 2008; Lucas \& Baras, 2001; Winter \& Fredrich, 2003). Gudgeon does not migrate, but does require suitable spawning grounds, leading to migration from stagnant to running waters (Brevé et al., 2014). Stone loach is a typical lowland stream species that hardly migrates (Brevé et al., 2014). The fish distribution data were obtained from the RAVON database (www.ravon.nl, database retrieved September 2016 that includes monitoring data of the local water authorities during the years 1990-2014 and monitoring data of volunteers, with a total of 6800 monitoring samples). The data of the years 2005-2014 were used for this analysis as the possibility for fish to migrate had been restored before 2005. As most sites were not monitored yearly, the data were grouped in periods of several years to exclude effects of differences in monitoring effort. Furthermore, only presence-absence was taken into account as taxon abundances regularly lacked. The historical 
distribution of fish species was extracted from the national and regional fish atlases for the period of about 70-100 years ago, long before most weirs were built (Brouwer, Dorenbosch, van Eekelen, \& Spier, 2010; de Nie, 1996).

The type of barriers, and the type and effectiveness of fish passages were retrieved from Brevé et al. (2014) and Kroes, Philipsen, and Wanningen (2018). In 10\% of the cases, a weir was fully removed. The fish passages referred to consisted of pool passes (50\%), technical passes (slot, denil, ladders, lifts, and locks) (24\%), vertical slot passes (4\%), and bypasses (12\%).

\section{2 | Selected lowland streams}

We selected eight slow-flowing, low-gradient lowland streams within the river Meuse catchment in the Netherlands: the Donge, Zandlei, Dommel, Aa, Raam, Loobeek, Molenbeek, and Sint Jansbeek (Figure 1a). The joint length of the studied streams was $1039 \mathrm{~km}$ and the width varied between $<3 \mathrm{~m}$ (37\%), 3-8 $\mathrm{m}$ (56\%), and 8-25 m (6\%). The number of barriers, their actual position, and the presence of fish passages were obtained from the regional water authorities (Figure 1b).

\section{3 | Stream fragmentation}

Two measures of stream fragmentation were quantified: the number of barriers (dams and weirs) between a specific stream section and the river Meuse and the length of the stream sections remaining between two barriers. Fish passages are not always effective and effectivity can differ between fish species (Foulds \& Lucas, 2013). The effectivity was investigated for 26 fish passages in this study area, thereby 25 were evaluated as effective and 1 was not functioning well (Kroes, Wanningen, van Puijenbroek, \&
Breve, 2015). The effectivity of the fish passages was also demonstrated by an increase in species distributions from before (19901999) and after (2004-2014) most fish passages were built (S.I. 2). Therefore, we concluded that most fish species were effective in this study area. The number of barriers between a specific stream section and the river Meuse was categorized into five classes: no barriers (always the case for the section between the river Meuse and the first barrier), 1 barrier, 2-3 barriers, 4-5 barriers, and $>5$ barriers. The length of the stream sections remaining between two barriers was categorized into five classes: $<1.0 \mathrm{~km}$ (very strongly fragmented), $1.0-2.50 \mathrm{~km}$ (strongly fragmented), $2.51-5.0 \mathrm{~km}$ (fragmented), 5.01-25.0 km (less fragmented), and $>25.0 \mathrm{~km}$ (not fragmented).

\section{$2.4 \quad$ Habitat and water quality}

We selected the Ecological Quality Ratio (EQR) of macroinvertebrates and their flow preferences as proxies to express local environmental conditions, since physicochemical grab sampling provides only a snapshot in time and space of habitat and water quality as experienced by biota (Metcalfe, 1989). In contrast to abiotic grab sampling, these macroinvertebrate indices integrate hydromorphological and physicochemical site characteristics over 6-12 months (Hellawell, 1986; Sládecek, 1973) and as they are based on the distribution of up to >2500 species, these indices are very distinctive (Hellawell, 1986; Sládecek, 1973). Moreover, data were available for the study area at the highest level of detail, providing the unique possibility to quantify habitat and water quality at the highest resolution possible at the scale of the present study, stream stretches of a few $\mathrm{km}$ between barriers.

The EQR-score based on macroinvertebrate community composition reflected the water quality of each stream section. The EQR is
FIGURE 1 Study area showing the tributaries Donge (1), Zandlei (2), Dommel (3), Aa (4), Raam (5), Loobeek, Molenbeek and Sint Jansbeek (6) of the river Meuse (a) and current location of barriers with $(n=458)$ and without $(n=123)$ fish passage (b) [Color figure can be viewed at wileyonlinelibrary.com] (a)

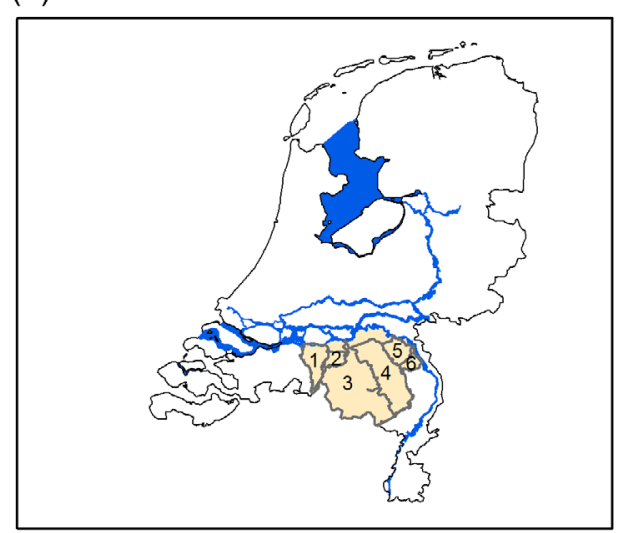

The Netherlands

Study area

Catchment border

Main rivers (b)

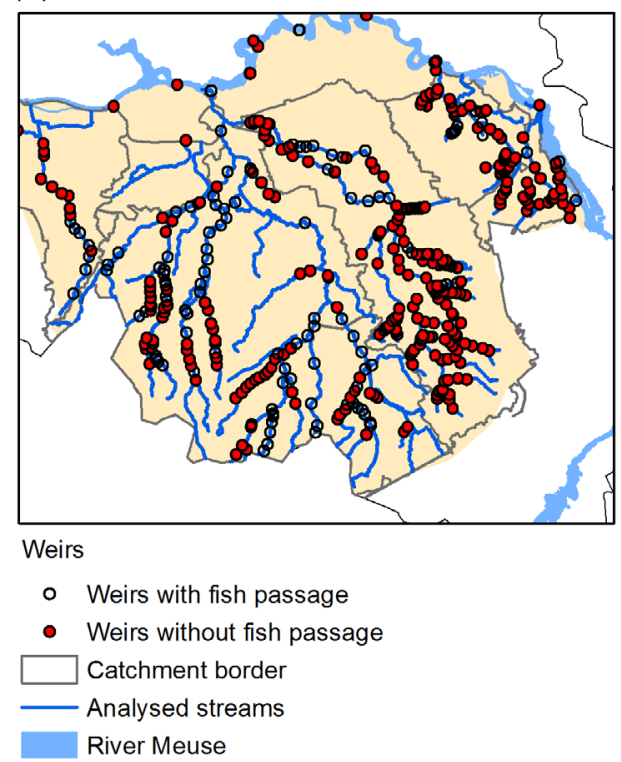


defined as the ratio between the water type specific reference and the observed presence of macroinvertebrates (van der Molen, Pot, Evers, \& van Nieuwerburgh, 2012) and ranges between 0 (very bad) and 1 (very good). The stream velocity index based on macroinvertebrate flow preferences reflected the habitat quality of each section. The stream velocity index was calculated using the stream velocity preference of macroinvertebrate species, classified as: 1 (still), 2 (very slow), 3 (slow), 4 moderate), and 5 (fast) (Verberk, Verdonschot, van Haaren, \& van Maanen, 2015). The macroinvertebrate data were obtained from the monitoring programs of the local water authorities during the years 2005-2014 in which each third year a site was sampled from site that showed little changes over time. Furthermore, macroinvertebrate sampling sites and fish monitoring sites were considered comparable when located within $2 \mathrm{~km}$ from each other within physically comparable stream sections.

\subsection{Statistical analysis}

To test whether there was a relationship between the EQR and stream section length (10 log transformed) and between stream velocity and stream section length, linear regressions were performed in TIBCO Spotfire $\mathrm{S}+{ }^{\circledR} 8.2$ for Windows. To evaluate if the absence of fish species could be related to poor habitat and water quality, the EQR and stream velocity indices were tested for significant differences between the categories "the fish species is present whether the section is accessible from the river Meuse or not" and "the fish species is absent, although the section is accessible from the Meuse", using a non-parametric test (Wilcoxon rank-sum test with Splus using TIBCO Spotfire $\mathrm{S}+{ }^{\circledR} 8.2$ for Windows). The last category was restricted to those stream sections where the species occurred based on its historical distribution.

\section{3 | RESULTS}

\section{1 | Stream fragmentation}

In total, 458 barriers occurred in the studied streams, of which 123 are now equipped with some type of fish passage. $79 \%$ of the $1039 \mathrm{~km}$ stream length was disconnected from the river Meuse by one or more barriers and $34 \%$ by more than 5 barriers (Figure 2a, Table 1). As most fish passages were constructed between 1990 and 2004 (Kroes et al., 2018), the related weirs were labeled inaccessible before 1990, and partly accessible in the period 2005-2014. In general, most disconnected stream sections were short, with an average stream section length less than $5 \mathrm{~km}$. $28 \%$ of all stream sections was even shorter than $2.5 \mathrm{~km}$ (Figure $2 \mathrm{~b}$ ).

\subsection{Habitat and water quality}

The EQR index indicated that the vast majority of the sites (91\%) were characterized by a bad, poor or moderate water quality, while only $7 \%$ of sites scored a good water quality and only $2 \%$ a very good water quality (Figure 3a). All study sites were characterized by slow (0.1$0.15 \mathrm{~m} / \mathrm{s})$ to very slow $(0.05-0.09 \mathrm{~m} / \mathrm{s})$ flowing waters, with only 3 sites (3\%) having a moderate $(0.16-0.25 \mathrm{~m} / \mathrm{s})$ stream velocity (Figure 3b).

Both the EQR and the stream velocity index increased with increasing stream section length (Figure 4). The EQR and the stream velocity index were not significantly related to the number of barriers.

Exploring the species-specific responses to stream fragmentation showed that chub and dace were present in only half of the number of stream sections upstream of the most downstream barrier and were hardly observed upstream of two or more barriers (Figure 5a, (a)

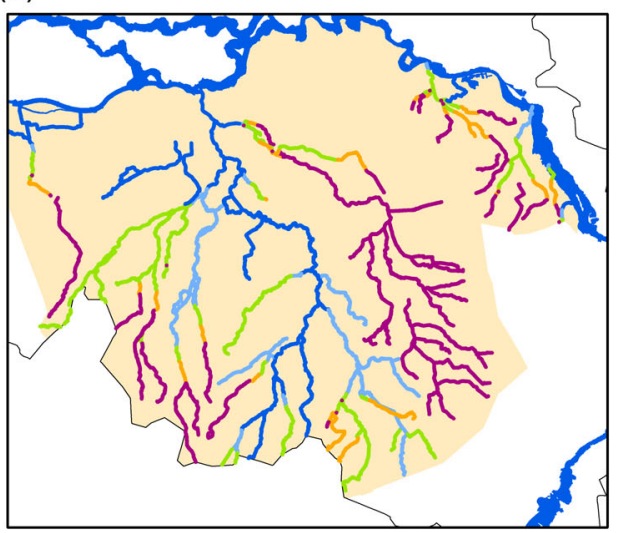

Number of weirs

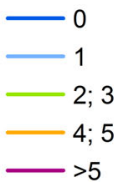

(b)

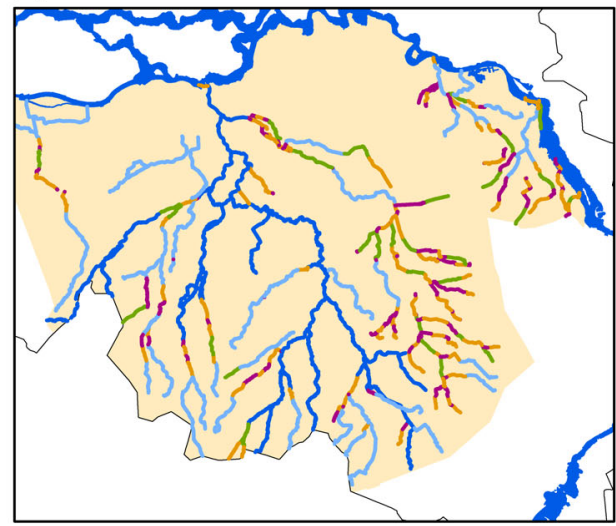

Length of stream sections $(\mathrm{km})$

$25-160$

$5-25$

$2.5-5$

$1-2.5$

$-<1$
FIGURE 2 Number of barriers between a specific stream section and the river Meuse (a) and the length of stream sections in between two barriers without a fish passage (b) [Color figure can be viewed at wileyonlinelibrary.com] 
TAB LE 1 Number of stream sections monitored in the period 2005-2015, categorized by length classes and by number of weirs

\begin{tabular}{|c|c|c|c|c|c|c|}
\hline Length classes (km) & Number of stream sections & \multicolumn{5}{|c|}{ Number of weirs } \\
\hline$>25$ & $4(28)$ & $1(14)$ & $2(10)$ & $1(4)$ & $0(0)$ & $0(0)$ \\
\hline $5-25$ & $37(34)$ & $4(6)$ & $3(3)$ & $11(10)$ & $4(3)$ & $15(11)$ \\
\hline $2.5-5$ & $31(10)$ & $2(1)$ & $2(1)$ & $4(1)$ & $2(1)$ & $21(7)$ \\
\hline $1-2.5$ & $117(18)$ & $2(0)$ & $11(2)$ & $23(4)$ & $17(3)$ & $64(10)$ \\
\hline Total & $442(100)$ & $9(21)$ & $29(16)$ & $73(21)$ & $44(8)$ & $287(34)$ \\
\hline
\end{tabular}

Note: Between brackets, the percentage of the length of the stream sections compared to the total length of all analyzed streams (1039 km) is given.

FIGURE 3 Habitat quality expressed as ecological quality ratio (EQR) based on macroinvertebrate community composition (a) and stream velocity index (b) [Color figure can be viewed at wileyonlinelibrary.com] (a)

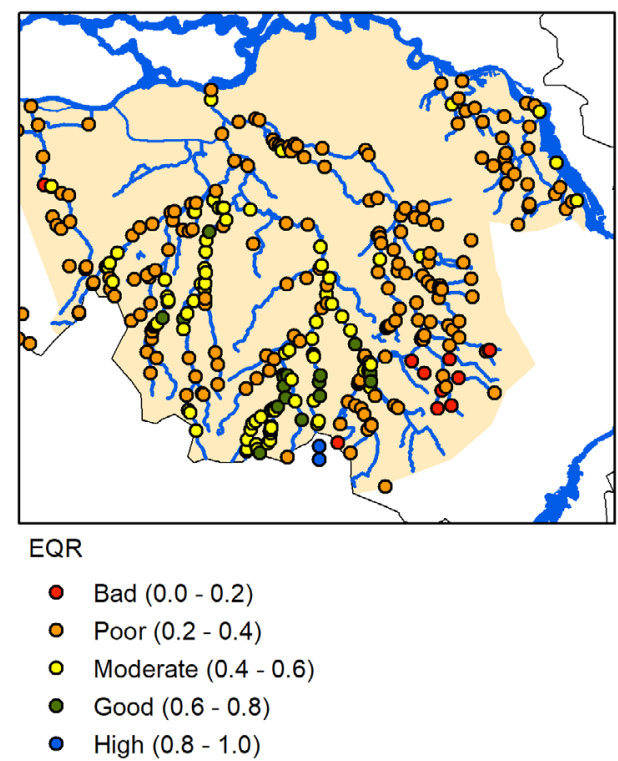

(b)

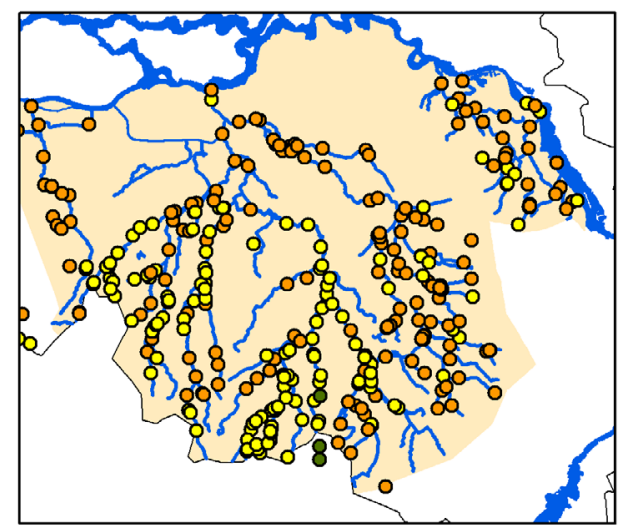

Flow velocity index

- Stagnant $(<0.05 \mathrm{~m} / \mathrm{s})$

- Very slowly $(0.05-0.09 \mathrm{~m} / \mathrm{s})$

- Slowly $(0.10-0.15 \mathrm{~m} / \mathrm{s})$

- Moderate $(0.16-0.25 \mathrm{~m} / \mathrm{s})$

- Fast $(>0.25 \mathrm{~m} / \mathrm{s})$
FIGURE 4 Relationship between the EQR and the section length (a) and the stream velocity index and the section length (b). The regression models were $\mathrm{EQR}=0.1329{ }^{*} \mathrm{log}$ (section length) +0.2979 , (R2 = 0.21, $p$-value $=3.25 \mathrm{e}^{* 10}$-6); stream velocity index $=0.3354 *$ log (section length) +1.8331 $(\mathrm{R} 2=0.17, p$-value $=3.299 * 10-6)$, respectively. Types of trend lines were logarithmic, section length in $\mathrm{m}$ (a)

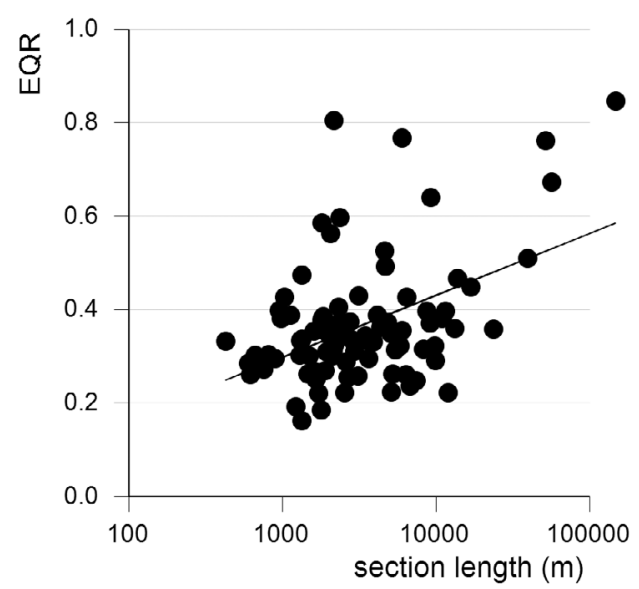

(b)

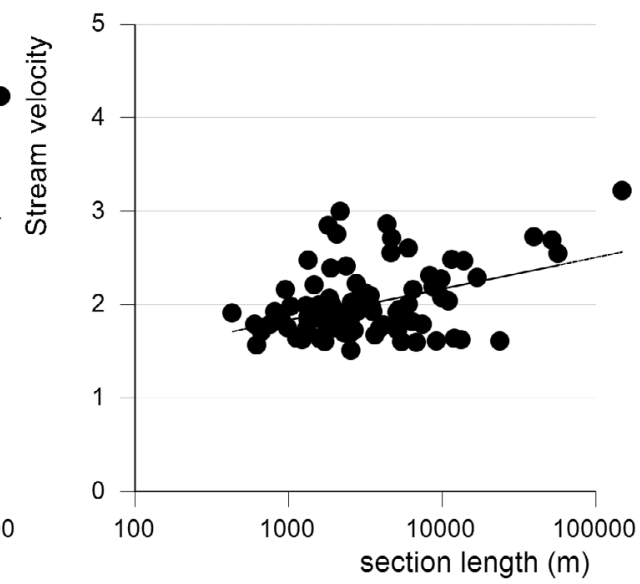

Table 2, Supplementary Information). In contrast, the distribution of stone loach and gudgeon was hardly reduced by upstream barriers. Ide showed an intermediate response with a lower presence upstream of barriers compared to sections without barriers. The shorter the stream section, the fewer fish were present (Figure 5b). Chub and dace were hardly observed upstream of the downstream-most barrier 
and therefore no relation with stream section length was observed. Ide, stone loach, and gudgeon occurred in 55,92 , and $85 \%$ of the sections shorter than $2.5 \mathrm{~km}$, respectively, in comparison to the occurrence in sections longer than $2.5 \mathrm{~km}$, indicating that the presence of ide was more affected by short section length than the presence of stone loach and gudgeon.

\subsection{Effects of habitat and water quality on riverine fish distribution}

Stream sections where chub and dace were present had a significant $(p<.05)$ higher EQR and stream velocity index in comparison to those where ide, stone loach, and gudgeon occurred (Figure 6), indicating (a)

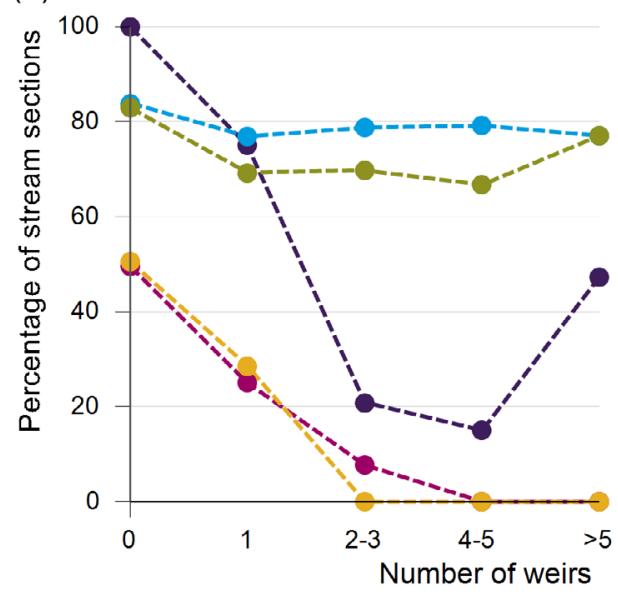

(b)

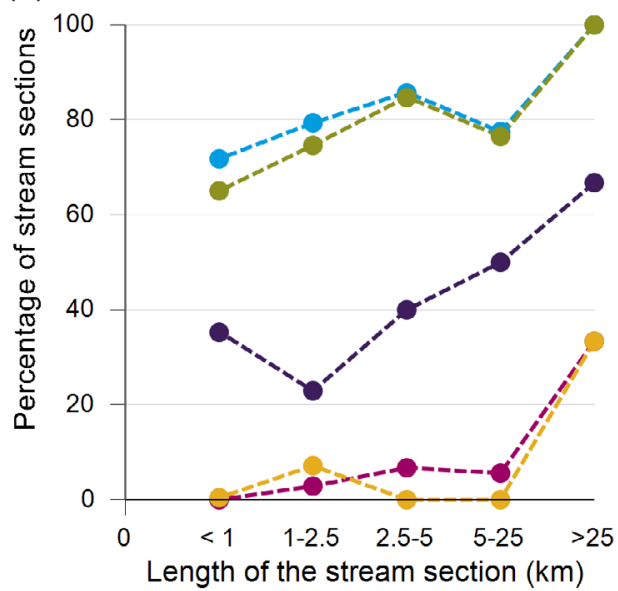

FIGURE 5 Effects of fragmentation on fish distribution expressed as the percentage of stream sections where the species is present plotted against the number of barriers between that specific stream section and the river Meuse (a) and the length of the remaining stream section in between two barriers or between the most downstream weir without a fish passage and the river Meuse in $\mathrm{km}$ (b) [Color figure can be viewed at wileyonlinelibrary.com]

Species

- Chub Dace Ide - Stone loach $\bullet$ Gudgeon

TAB LE 2 Current occurrence of the five fish species expressed as percentage of total historical stream length and as percentage of total historical number of sections

\begin{tabular}{|llllll|}
\hline & Chub & Dace & Ide & Loach & Gudgeon \\
\hline Stream length (\%) & 38 & 45 & 58 & 89 & 87 \\
\hline Number of sections (\%) & 6 & 11 & 26 & 78 & 74 \\
\hline
\end{tabular}

(a)

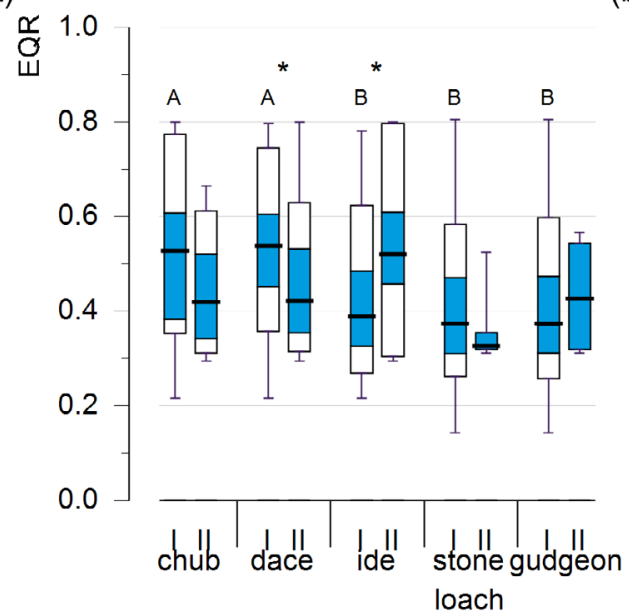

(b)

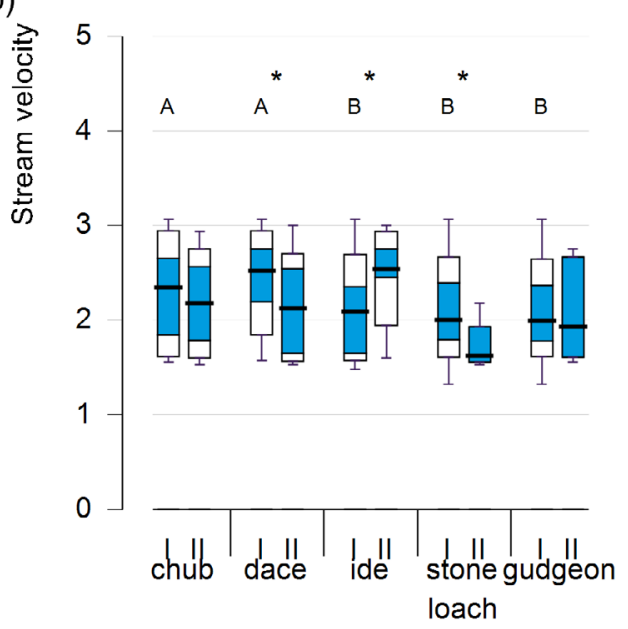

FIGURE 6 Ecological quality ratio (a) and stream velocity index (b) of locations where the species was present whether accessible or not (I) or absent at accessible locations (II). Significant differences $(p<.05)$ between species present whether accessible or not are indicated with the letters $A$ and $B$ and between the two categories per species with * [Color figure can be viewed at wileyonlinelibrary.com] 
that chub and dace have higher habitat and water quality requirements than the other three species. This was reflected by the higher EQR and stream velocity index at sites where chub and dace were present compared to sites where these two species were absent, which was significant $(p<.05)$ in the case of dace. In addition, also stream sections where stone loach was present had significant $(p<.05)$ higher stream velocity compared to sections where it was absent. For EQR and stream velocity in the case of gudgeon and EQR in the case of stone loach there was no difference between sites where the species was present or absent. Remarkably, the sections where ide occurred were characterized by a significantly lower EQR and stream velocity index compared to sections where it was absent.

\section{4 | DISCUSSION}

\section{1 | Effects of stream fragmentation on riverine fish distribution}

To isolate the impact of stream fragmentation from that of poor habitat and water quality, the absence of fish species from inaccessible streams independent from the ecological quality may be indicative. Considering the presence of the selected fish species upstream of the most downstream barrier showed that gudgeon and stone loach were hardly affected by stream fragmentation. These species were only slightly limited by too short stream sections $(<1 \mathrm{~km})$ with low flow conditions. Ide was moderately affected since the response to decreasing stream section length was quite strong. The migratory species chub and dace were severely affected by stream fragmentation. The varying impact of stream fragmentation on the selected fish species clearly reflected their migration behavior. Chub and dace migrate upstream to spawn and between habitat patches, using these for different functions (de Leeuw \& Winter, 2008; Lothian et al., 2019; Lucas \& Baras, 2001; Pollux et al., 2006). Migration of ide may vary substantially between individuals within a single population, ranging from only a few km to up to $100 \mathrm{~km}$ (Brevé et al., 2014; de Leeuw \& Winter, 2008; Lucas \& Baras, 2001; Winter \& Fredrich, 2003). Stone loach and gudgeon, the two species that were hardly affected by barriers in the present study, have resident populations living in a specific stream section for their entire life-cycle (Pollux et al., 2006; Vinyoles et al., 2010). It is concluded that stream fragmentation limited the distribution of riverine fish in the presently studied lowland streams in a species-specific way, raising the question of how this impact relates to the coinciding effects of poor habitat and water quality.

\subsection{Effects of habitat and water quality on riverine fish distribution}

Indications of the impact of poor habitat and water quality independent from that of stream fragmentation may be obtained from comparing the EQR and stream velocity indices between sites where the fish was either present or absent and by comparing the presence and absence of species in accessible streams with varying ecological quality. These comparisons showed that chub and dace were more sensitive to poor habitat and water quality than ide, stone loach, and gudgeon. Stream sections where chub and dace were present were characterized by a higher ecological quality ratio and stream velocity index than the sections where the other species were present. The higher ecological quality demands of these two sensitive species were also reflected by the absence of these species in $50 \%$ of the accessible streams.

Although fish are one of four biological quality elements in the monitoring of ecological water quality according to the EU WFD, little information is available on the relative sensitivity of fish species to poor habitat and water quality. Mueller, Pander, and Geist (2018) analyzed over 30 years of data on stream fish population trends in Germany. They showed that chub and dace strongly declined in spatial distribution and abundance during the analyzed period, attributed to agricultural land-use, river regulations, higher water temperatures, increased fine sediment loads, and altered flow dynamics (Mueller et al., 2018). In contrast, an increase in the abundance of stone loach and gudgeon was observed, explained by a higher tolerance to structural degradation (Jurajda, 1995; Mueller et al., 2018; Pander \& Geist, 2010). These findings match well with the present observations of the higher sensitivity of chub and dace compared to stone loach and gudgeon. Hence, in addition to stream fragmentation, also habitat deterioration and poor water quality affected the selected fish species in a species-specific way. Restoring populations of riverine fish species may thus require a tailor-made approach acknowledging both stream fragmentation and ecological quality as well as the interactions between these.

\section{3 | Restoring populations of riverine fish species}

The worst-case scenario comprised inaccessible streams with short stream sections, characterized by poor habitat and water quality and reduced flow. At such locations, only stone loach and gudgeon were present. These species still occurred at sites with a poor to moderate ecological quality, with slow-flowing to almost stagnant flow conditions and where the sandy bottom was covered with fine sediments. Moreover, they were present in $80 \%$ of the stream sections that were disconnected from the main river by 5 or more barriers and in approximately $70 \%$ of the stream sections shorter than $1 \mathrm{~km}$, although the presence of these species was to some extent affected by such short stream section lengths. Hence, building fish passages to connect fragmented stream sections shorter than $1 \mathrm{~km}$ to sections longer than $5 \mathrm{~km}$ may slightly improve the distribution of stone loach and gudgeon.

Yet, fish passages do not improve poor ecological quality and flow conditions, since the barriers remain present, impounding the upstream sections. Especially short impounded sections in lowland streams have nearly only stagnant water(Birnie-Gauvin et al., 2017). Stagnant water is the most relevant stress factor for fish communities in headwater stream fish communities (Bierschenk, Mueller, Pander, \& 
Geist, 2019; Mueller, Bierschenk, Bierschenk, Pander, \& Geist, 2020)). Hence, building fish passages without additional measures to improve habitat quality will only aid the species with low demands for ecological quality, while for the more sensitive species, especially chub and dace, building fish passages obviously does not suffice.

The present study showed that both the EQR and the stream velocity index increased with increasing stream section length, indicating that besides fragmentation the poor habitat and water quality may also be related to the presence of the barriers and the length of the remaining stream sections. Barriers reduce stream velocity, minimize substrate variation, and reduce dissolved oxygen concentrations (Birnie-Gauvin et al., 2017; Bunn \& Arthington, 2002; Fuller et al., 2015; Petts, 1984; Poff $\&$ Hart, 2002). This is especially the case for the presently studied low-gradient lowland streams, characterized by short stream sections and gentle slopes that extend the adverse effects of the barriers over long distances (Birnie-Gauvin et al., 2017). The complete removal of barriers is thus a better restoration measure, from which more riverine species will likely benefit, as the habitat quality improves when the impounded section upstream the barrier becomes free-flowing again.

Poor habitat and water quality are not only caused by barriers, since freshwater ecosystems in densely populated, heavily exploited lowland areas are also impacted by pollution, resulting in poor water quality (de Baat et al., 2019; de Vries et al., 2019; dos Reis Oliveira et al., 2018; Paul \& Meyer, 2001; Riis \& Sand-Jensen, 2001). To allow the most sensitive species to return, stream fragmentation, habitat deterioration, and poor water quality should, therefore, be addressed simultaneously. Otherwise, in cases where the species occurred historically, but where the current habitat quality is insufficient, there is a risk that the investment by improving connectivity will not result in the return of the species (Aarts et al., 2004; Verdonschot \& Nijboer, 2002). Such mismatches between restoration goals and restoration measures may explain why despite increasing restoration efforts success rates are still rather low (dos Reis Oliveira et al., 2020). Evaluating over 40 years of stream restoration these authors advised to first diagnose the dominant stressors and then plan the appropriate combination of restoration measures (dos Reis Oliveira et al., 2020).

In conclusion, distinguishing the species-specific effects of stream fragmentation, habitat deterioration and poor water quality on lowland stream fish distribution increased the understanding of the reasons for the presence and absence of species and may aid effective management and support restoration efforts.

\section{DATA AVAILABILITY STATEMENT}

The data that support the findings of this study are available from the corresponding author. Restrictions apply to the availability of the fish monitoring database, which were used under license for this study.

\section{ORCID}

Peter J.T.M. van Puijenbroek (D) https://orcid.org/0000-0001-63702411

\section{REFERENCES}

Aarts, B. G. W., van den Brink, F. W. B., \& Nienhuis, P. H. (2004). Habitat loss as the main cause of the slow recovery of fish faunas of regulated large rivers in Europe: The transversal floodplain gradient. River Research and Applications, 20, 3-23.

de Baat, M. L., Kraak, M. H. S., van der Oost, R., de Voogt, P., \& Verdonschot, P. F. M. (2019). Effect-based nationwide surface water quality assessment to identify ecotoxicological risks. Water Research, 159, 434-443.

Belletti, B., Garcia de Leaniz, C., Jones, J., Bizzi, S., Börger, L., Segura, G., ... Zalewski, M. (2020). More than one million barriers fragment Europe's rivers. Nature, 588, 436-441.

Bierschenk, A. M., Mueller, M., Pander, J., \& Geist, J. (2019). Impact of catchment land use on fish community composition in the headwater areas of Elbe, Danube and Main. Science of The Total Environment, 652, 66-74.

Birnie-Gauvin, K., Aarestrup, K., Riis, T. M. O., Jepsen, N., \& Koed, A. (2017). Shining a light on the loss of rheophilic fish habitat in lowland rivers as a forgotten consequence of barriers, and its implications for management. Aquatic Conservation: Marine and Freshwater Ecosystems, 27, 1345-1349.

Blanchet, S., Rey, O., Etienne, R., Lek, S., \& Loot, G. (2010). Species-specific responses to landscape fragmentation: Implications for management strategies. Evolutionary Applications, 3, 291-304.

Brevé, N. W. P., Buijse, A. D., Kroes, M. J., Wanningen, H., \& Vriese, F. T. (2014). Supporting decision-making for improving longitudinal connectivity for diadromous and potamodromous fishes in complex catchments. Science of the Total Environment, 496, 206-218.

Brouwer, T., Dorenbosch, M., van Eekelen, R., \& Spier, J. (2010). Vissenatlas Noord-Brabant. Bedum: Uitgeverij Profiel.

Brown, J. J., Limburg, K. E., Waldman, J. R., Stephenson, K., Glenn, E. P., Juanes, F., \& Jordaan, A. (2013). Fish and hydropower on the U.S. Atlantic coast: Failed fisheries policies from half-way technologies. Conservation Letters, 6, 280-286.

Bunn, S. E., \& Arthington, A. H. (2002). Basic principles and ecological consequences of altered flow regimes for aquatic biodiversity. Environmental Management, 30, 492-507.

Calles, O., Rivinoja, P., \& Greenberg, L. (2013). A historical perspective on downstream passage at hydroelectric plants in Swedish rivers. In I. Maddock, A. Harby, P. Kemp, \& P. Wood (Eds.), Ecohydraulics: An integrated approach (1st ed.). Hoboken, NJ, Ltd: John Wiley \& Sons.

Cote, D., Kehler, D. G., Bourne, C., \& Wier, Y. F. (2008). A new measure of longitudinal connectivity for stream networks. Landscape Ecology, 24, 101-113.

dos Reis Oliveira, P. C., Kraak, M. H. S., van der Geest, H. G., Naranjo, S., \& Verdonschot, P. F. M. (2018). Sediment composition mediated land use effects on lowland streams ecosystems. Science of the Total Environment, 631-632, 459-468.

dos Reis Oliveira, P. C., van der Geest, H. G., Kraak, M. H. S., Westveer, J. J., Verdonschot, R. C. M., \& Verdonschot, P. F. M. (2020). Over forty years of lowland stream restoration: Lessons learned? Journal of Environmental Management, 264, 110417.

Dudgeon, D., Arthington, A. H., Gessner, M. O., Kawabata, Z.-I., Knowler, D. J., Lévêque, C., ... Sullivan, C. A. (2006). Freshwater biodiversity: Importance, threats, status and conservation challenges. Biological Reviews, 81, 163-182.

Fahrig, L. (2003). Effects of habitat fragmentation on biodiversity. Annual Review of Ecology, Evolution, and Systematics, 34, 487-515.

Foulds, W. L., \& Lucas, M. C. (2013). Extreme inefficiency of two conventional, technical fishways used by European river lamprey (Lampetra fluviatilis). Ecological Engineering, 58, 423-433.

Fuller, M. R., Doyle, M. W., \& Strayer, D. L. (2015). Causes and consequences of habitat fragmentation in river networks. Annals of the New York Academy of Sciences, 1355, 31-51.

Fullerton, A. H., Burnett, K. M., Steel, E. A., Flitcroft, R. L., Press, G. R., Feist, B. E., ... Sanderson, B. L. (2010). Hydrological connectivity for riverine fish: Measurement challenges and research opportunities. Freshwater Biology, 55, 2215-2237. 
Guo, Q., Liu, X., Ao, X., Qin, J., Wu, X., \& Ouyang, S. (2018). Fish diversity in the middle and lower reaches of the Ganjiang River of China: Threats and conservation. PLoS ONE, 13, e0205116.

Harris, J. H., Kingsford, R. T., Peirson, W., \& Baumgartner, L. J. (2017). Mitigating the effects of barriers to freshwater fish migrations: The Australian experience. Marine and Freshwater Research, 68, 614-628.

Hellawell, J. M. (1986). Biological indicators of freshwater pollution and environmental management. Amsterdam: Elsevier.

Jones, J., Börger, L., Tummers, J., Jones, P., Lucas, M., Kerr, J., ... Garcia de Leaniz, C. (2019). A comprehensive assessment of stream fragmentation in Great Britain. Science of the Total Environment, 673, 756-762.

Jurajda, P. (1995). Effect of channelization and regulation on fish recruitment in a floodplain river. River Research and Applications, 10, 207-215.

Kroes, M.J., Philipsen, P., Wanningen, H. (2018). Nederland leeft met vismigratie. Actualisatie landelijke database vismigratie. In opdracht van Rijkswaterstaat, Sportvisserij Nederland, Wageningen Marine Research, Planbureau voor de Leefomgeving.

Kroes, M. J., Wanningen, H., van Puijenbroek, P., Breve, N. (2015). Nederland leeft met vismigratie. Actualisatie landelijke database vismigratie. Sportvisserij Nederland, PBL, Bilthoven.

de Leeuw, J. J., \& Winter, H. V. (2008). Migration of rheophilic fish in the large lowland rivers Meuse and Rhine, the Netherlands. Fisheries Management and Ecology, 15, 409-414.

Lothian, A. J., Gardner, C. J., Hull, T., Griffiths, D., Dickinson, E. R., \& Lucas, M. C. (2019). Passage performance and behaviour of wild and stocked cyprinid fish at a sloping weir with a low cost baffle fishway. Ecological Engineering, 130, 67-79.

Lucas, M. C., \& Baras, E. (2001). Migration of freshwater fishes. Hoboken, NJ: Blackwell Science.

Metcalfe, J. L. (1989). Biological water quality assessment of running waters based on macroinvertebrate communities: History and present status in Europe. Environmental Pollution, 60, 101-139.

van der Molen, D. T., Pot, R., Evers, C. H. M., \& van Nieuwerburgh, L. L. J. (2012). Referenties en maatlatten voor natuurlijke wateren voor de Kaderrichtlijn Water 2015-2021. Engelsbrand: Stowa.

Mueller, M., Bierschenk, A. M., Bierschenk, B. M., Pander, J., \& Geist, J. (2020). Effects of multiple stressors on the distribution of fish communities in 203 headwater streams of Rhine, Elbe and Danube. Science of the Total Environment, 703, 134523.

Mueller, M., Pander, J., \& Geist, J. (2011). The effects of weirs on structural stream habitat and biological communities. Journal of Applied Ecology, 48, 1450-1461.

Mueller, M., Pander, J., \& Geist, J. (2018). Comprehensive analysis of $>30$ years of data on stream fish population trends and conservation status in Bavaria, Germany. Biological Conservation, 226, 311-320.

de Nie, H. (1996). Atlas van de Nederlandse zoetwatervissen. Doetinchem, the Netherlands: Media Publishing.

Nilsson, C., Reidy, C. A., Dynesius, M., \& Revenga, C. (2005). Fragmentation and flow regulation of the world's large river systems. Science, 308, 405-408.

Noble, R. A. A., Cowx, I. G., Goffaux, D., \& Kestemont, P. (2007). Assessing the health of European rivers using functional ecological guilds of fish communities: Standardising species classification and approaches to metric selection. Fisheries Management and Ecology, 14, 381-392.

Pander, J., \& Geist, J. (2010). Seasonal and spatial bank habitat use by fish in highly altered rivers: A comparison of four different restoration measures. Ecology of Freshwater Fish, 19, 127-138.

Paul, M. J., \& Meyer, J. L. (2001). Streams in the urban landscape. Annual Review of Ecology, Evolution, and Systematics, 32, 333-365.

Petts, G. E. (1984). Impounded rivers: Perspectives for ecological management. Hoboken, NJ: John Wiley \& Sons.
Poff, N. L., \& Hart, D. D. (2002). How dams vary and why it matters for the emerging science of dam removal: : An ecological classification of dams is needed to characterize how the tremendous variation in the size, operational mode, age, and number of dams in a river basin influences the potential for restoring regulated rivers via dam removal. Bioscience, 52, 659-668.

Pollux, B. J. A., Korosi, A., Verberk, W. C. E. P., Pollux, P. M. J., \& van der Velde, G. (2006). Reproduction, growth, and migration of fishes in a regulated lowland tributary: Potential recruitment to the river Meuse. Hydrobiologia, 565, 105-120.

van Puijenbroek, P. J. T. M., Buijse, A. D., Kraak, M. H. S., \& Verdonschot, P. F. M. (2019). Species and river specific effects of river fragmentation on European anadromous fish species. River Research and Applications, 35, 68-77.

Radinger, J., Essl, F., Hölker, F., Horký, P., Slavík, O., \& Wolter, C. (2017). The future distribution of river fish: The complex interplay of climate and land use changes, species dispersal and movement barriers. Global Change Biology, 23, 4970-4986.

Riis, T., \& Sand-Jensen, K. (2001). Historical changes in species composition and richness accompanying perturbation and eutrophication of Danish lowland streams over 100 years. Freshwater Biology, 46, 269-280.

Sládecek, V. (1973). System of water quality from the biological point of view. Port Jervis, NY: Lubrecht \& Cramer.

Stanford, J. A., \& Ward, J. V. (2001). Revisiting the serial discontinuity concept. Regulated Rivers: Research \& Management, 17, 303-310.

Verberk, W. C. E. P., Verdonschot, P. F. M., van Haaren, T., \& van Maanen, B. (2015). Milieu- en habitatopreferentie van Nederlandse zoetwatermacrofauna. Nijmegen, the Netherlands: Werkgroep Ecologisch Waterbeheer (WEW), Subgroep Autoecologie.

Verdonschot, P. F. M., \& Nijboer, R. C. (2002). Towards a decision support system for stream restoration in The Netherlands: An overview of restoration projects and future needs. Hydrobiologia, 478, 131-148.

Vinyoles, D., de Sostoa, A., Franch, C., Maceda-Veiga, A., Casals, F., \& Caiola, N. (2010). Life-history traits of the stone loach Barbatula barbatula. Journal of Fish Biology, 77, 20-32.

de Vries, J., Kraak, M. H. S., Verdonschot, R. C. M., \& Verdonschot, P. F. M. (2019). Quantifying cumulative stress acting on macroinvertebrate assemblages in lowland streams. Science of the Total Environment, 694, 133630.

Ward, J., \& Stanford, J. (1983). The serial discontinuity concept of lotic ecosystems. In T. D. Fontaine \& S. M. Bartell (Eds.), Dynamics of Lotic Ecosystems. Palo Alto, CA: Ann Arbor Science.

Winter, H. V., \& Fredrich, F. (2003). Migratory behaviour of ide: A comparison between the lowland rivers Elbe, Germany, and Vecht, the Netherlands. Journal of Fish Biology, 63, 871-880.

WWF. (2016). Living planet report 2016: Risk and resilience in a new era. Gland: WWF International.

\section{SUPPORTING INFORMATION}

Additional supporting information may be found online in the Supporting Information section at the end of this article.

How to cite this article: van Puijenbroek, P. J. T. M., Buijse, A. D., Kraak, M. H. S., \& Verdonschot, P. F. M. (2021). Through the dam into troubled waters: Combined effects of stream fragmentation, habitat deterioration, and poor water quality on lowland stream fish distribution. River Research and Applications, 1-9. https://doi.org/10.1002/rra.3829 